\title{
Divisional Activities
}

\section{The North-West Division's Year: 1981-2}

It has become the custom for our Annual General Meeting to be held at an interesting hospital, with a business meeting and discussions of a special topic in the mornings and, following lunch, the trainees of the Division are invited to present their research. As each year passes one is, yet again, impressed by their projects and their presentation. Currently they emanate almost exclusively from the Manchester trainees scheme. They are considerably influenced by Dr Peter Maguire.

The 1981 Annual General Meeting was held at Greaves Hall Hospital, Southport. Dr Keith Rix entertainingly confirmed for us that alcohol dependence was a serious problem in Scottish fishermen. Dr Frank Margison described the Mother and Baby Unit serving the North-Western RHA and showed psychotic mothers to be less harmful for their children than those who were personality disordered.

The 1982 Annual General Meeting, held at Winwick Hospital, also proved rewarding. Dr Stephen Riley showed that self-mutilation and self-poisoning carried a worse prognosis than self-poisoning alone. Dr Susan Benbow confirmed self-poisoning in children to be more deliberate with the child's increasing age. Dr Keith Bridges, expanding the appraisal of psychiatric awareness in other specialties to neurology, found such patients had only a 1 in 4 chance of detection of psychiatric morbidity.

Dr Brian Ward outlined in the Special Topic the possible developments of mental hospitals for the next twenty-five years. Special Units to complement the community services based on the District General Hospitals seemed the most desirable.

Withington Hospital, the University Hospital of South Manchester, was once again our host for the meeting of November 1981 at which we were given an appetizing taste of the work being undertaken in the study of the teaching of psychotherapy. This formed the basis for what many thought to be the highlight of the Division's academic contribution to the Spring 1982 Quarterly Meeting of the College in Liverpool.

The Spring Quarterly Meeting (19 to 21 April 1982) commenced with a meeting at the historic Liverpool Medical Institution. The Nursing Process appears to fulfil the professional aspirations of many nurses, but it would appear to have a major flaw in that more qualified nurses will be essential for such standards to be attained.

The Town Hall of Liverpool, of the era of wealth and expansion, provided a rich contrast to the poverty of some parts of the city and was the venue for the Lord Mayor's Reception.

The standard of the academic sessions was extremely high and will be reported elsewhere. The meeting was complemented by the official dinner and lunch at the Royal
Liverpool Hospital. Parallel sessions, a pattern our Division attempted to resist, made it impossible to enjoy all that occurred in the communications.

Trainees' Day 1982 concentrated upon current topicsmanpower, mental health legislation and electroplexy with the showing of a film from the Manchester Department of Psychiatry on the latter subject. Dr David Finnegan and Dr Neill Simpson's organization was amply rewarded.

Elections in the Division have brought some changes. The Chairman is now Dr Angus Campbell and the Honorary Secretary is Dr I. B. Cookson. Dr David Enoch has put much time, effort and enormous enthusiasm into his four years as Chairman and the Executive Committee is fortunate to retain his influence. In recognition he received a plaque of the College Coat of Arms at the Annual General Meeting which was presented by Dr Mike Cashman, the Fellow on Council.

I. B. Cookson

Honorary Secretary

\section{Irish Division: Anuual Meeting 1982}

The Annual Meeting of the Irish Division took place in St John of God's Hospital, Stillorgan, Co Dublin, on 29 October 1982. The theme of this year's clinical section was 'Genetics in Psychiatry'. Three excellent papers were presented. The first, 'Genetics of normal and abnormal sexual differentiation', was delivered by Professor Joseph Masterson, who, in a masterfully clear exposition of the subject, took us all back to our medical student years. The second paper, by Dr Valerie Cowie and entitled 'Psychiatric implications of sex chromosome abnormalities', described in detail the four main syndromes associated with such abnormalities. The third paper, delivered in the afternoon by Dr Robin Murray, 'Recent twin studies in psychiatry', concentrated on new studies, particularly in the field of schizophrenia and alcoholism. He posed the question that there may be two types of schizophrenia, one with an organic component and associated with birth trauma and enlarged ventricles, and the other genetically endowed. All three papers provoked lively discussion and the meeting was brought to a successful conclusion when the difficult task of summarizing the papers was ably performed by Dr Michael Kelleher.

The Business Meeting, chaired by Professor Thomas Lynch with the Registrar of the College, Professor Gerald Timbury, in attendance, discussed our recent meeting with Department of Health officials. Drastic cutbacks, affecting both facilities and manning of our health services, are threatening the quality of care of our patients. The Executive has instructed the officers of the Division to write to the 
Minister for Health and the Chief Executive Officers of all Health Boards, expressing our resistance to such cutbacks. The Executive has also requested that the Division express our reservations about the new post of Chief Psychiatrist within the Department of Health. The Honorary Secretary informed the meeting that he had received a communication from the Association of Administrative Psychiatric Nurses, expressing a desire to meet representatives of the Irish Division. This association is believed to hold similar viewpoints to our own on integrated nursing and promotion of nurses by seniority. It was agreed to convene a meeting with this Association in order to co-ordinate efforts to improve the quality of in-patient care. The next Quarterly Meeting of the Irish Division will take place at Castlebar on 15 and 16 April 1983.

At the Annual Dinner held in the Royal College of Surgeons, Dublin, members were informed of the death of Dr Frank McLaughlin, one of our most esteemed Fellows. A minute's silence was observed as a mark of respect.

The Minister for Health, in proposing the Toast to the Irish Division, Royal College of Psychiatrists, outlined a number of developments currently under way in the psychiatric services. He also underlined the challenges now confronting the services because of the financial stringencies imposed by the economic crisis.

The members of the Irish Division expressed their appreciation to Reverend Brother Prior, and Dr Desmond McGrath, Medical Director, of St John of God's Hospital, Stillorgan, for hosting such a successful meeting, in this the year of the 100th anniversary of the founding of the St John of God Brothers in Ireland.

DAvid Shanley

Honorary Secretary

\section{Chiltern and Thames Valley Division Trainees' Day}

The first Trainees' Day of the Chiltern and Thames Valley Division of the College took place on 15 September 1982 at St Crispin's Hospital, Northampton. Fifty-one trainees, seven clinical tutors and two deputy advisers of the College participated in a successful programme.

The topics were the formulation of a case, the Short Report and psychotherapy training, which we felt were all of current interest and relevance to trainees.

Jeremy Pfeffer of the London Hospital talked about the formulation; this was followed by an interesting discussion, particularly about different expectations of examiners and their inability to agree what they mean by a formulation. A competition for the best formulation was then arranged using a summary of a psychiatric case. This aroused much interest. Based on her experience as a trainee member of the Manpower Committee, Julie Hollyman gave an interesting talk on the Short Report and its implications for psychiatric education. The morning ended with a paper by Dennis Brown, who highlighted the therapeutic principles of psychotherapy and their relevance to psychiatric practice.

The afternoon opened with another paper on psychotherapy by Terry Lear, and was followed by Harry Tough's talk on psychotherapy in the General Hospital. This led to a discussion on the importance of psychotherapy in the practice of general psychiatry. The host clinical tutors, Diana Knight and Hema Ghadiali, then led a lively debate on the pros and cons of a Rotational Training Scheme in Psychiatry. Issues raised included the balance between service and training needs, many feeling that in peripheral hospitals training was suffering at the expense of service. Another issue was the length of posts; nine months was thought by many to be more useful than six months, and the need for a two-way feedback at the end of the post, not only from consultant to trainee, but also by the trainee on his experience of the placement. The final session was spent in a discussion on possible changes in the Membership exam and in viewing a video on interviewing skills.

Everyone attending thought this a successful day. Its topicality and relevance can perhaps best be judged by the fact that the September Bulletin contained an excellent article on formulation and the October Bulletin had contributions on the future of the Membership exam. However, it was disappointing that so few trainees were from teaching hospitals; this tended to reinforce the 'we and them' feeling between teaching and peripheral hospital trainees. We were also disappointed that so few clinical tutors attended, despite being personally invited, possibly reflecting an impression that clinical tutors are appointed as a reward for good service, rather than out of an interest in training. Let us hope that, having read this account, and hearing from the trainees who attended, they will realize the importance of Trainees' Days and come in future.

HARISH GADHVI RODGER MARTIN RAMAN SHARMa St. Crispin's Hospital, Northampton 